\title{
Volkmann's Ischemic Contracture
}

National Cancer Institute

\section{Source}

National Cancer Institute. Volkmann's Ischemic Contracture. NCI Thesaurus. Code C35130.

An ischemic contracture of the forearm that most often occurs secondary to trauma. 